\title{
?

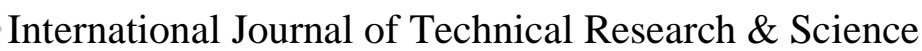 ASSESSMENT OF TECHNOGENIC IMPACT OF QAYYARAH OIL WELLS COMBUSTION ON SUSTAINABLE DEVELOPMENT IN IRAQ
}

\author{
Ibraheem M. Aliyas, Mohammad A. H. Alhadeedy \\ E-Mail Id: aboesamalnaser@yahoo.com \\ Northern Technical University, Mosul
}

\begin{abstract}
Oil or petrol is considered a conventional natural resource that must be protected from any damage, as it forms the key of the national income and the fundamental base for the Iraqi economy which is called the nerve of life \& black gold. Due to the American invasion which destroyed the infrastructure in Iraq by military forces, then the second page came through terrorism which last for more than 3 years to destroy the rest of the national economy, by burning the oil wells in Qayyarah region in Nineveh province. The terrorists have set 19 oil wells on fire out of 63 in May 2016. The burning of Qayyarah area oil fields south of Mosul city caused huge gaseous emissions such as carbon dioxide, Sulfur oxides, Nitrogen oxides, Organic compounds, carbon monoxide, particulate matter, methane etc. The above operations produced negative effects on sustainable development factors; Ecologically, Economically, and Socially. Ecologically; effects on atmosphere were very obvious by means of intensive smoke, sunlight curtain, shading, acid rains, temperature raising, prevention of cloud condensation, disruption of air components, increasing toxic elements in the atmosphere by increasing the proportion of carbon dioxide and carbon monoxide, and their influence on soil elements balance status, negative effects on soil microorganisms, influence on bio-processes between the producer, consumer and decomposer in energy flow, lowering land productivity, desertification, plant death and the influence on biological and physical, and chemical traits of water resources. Toxicity and suffocation were also common in the area of burning as a result of the movement of smoke clouds. Economically, biodiversity loss, oil production stoppage, seed germination failure in the exposed lands to military operations which reduced the yield, and general effects on the agricultural and livestock sectors which caused a big loss in the national economy. Then the rehabilitation of all these damages surely will cost a lot of money and effort to get rid of these wastes. Socially, the oil wells combustion caused human troubles such as poverty, death, immigration of farmers from their land, joblessness, education stoppage, various diseases such as cancer, asthma etc.
\end{abstract}

Keywords: Oil Burning, Qayyarah, Technogenic impact, Sustainable development, Nineveh, Iraq.

\section{INTRODUCTION}

The Iraqi ecosystem has been subjected to several noxious environmental pressures \& technogenic (anthropogenic) challenges due to the effects of four wars (1980-1988, 1991, 2003, 2014) which caused; climate changes, land degradation, encroachment of fragile ecosystems, drought, poor water quality, soil salinity, air pollution, water shortages and desertification. All these factors are negatively reflected on sustainable development [1,2]. Iraq has natural economic resources such as; petrol and natural gas, mineral resources; (sulfur, phosphorus and silicon...etc.), water resources, fertile land, human resources, scientific skills, investments and suitable environment, which made Iraq a prosperous country. But the wars prevented Iraq from the achievement of comprehensive development, as the infrastructure were destroyed and that was reflected on productivity and service sectors, which were damaged and this damage included all aspects of life, including environment, society, economy, and land desertification [3,4]. Oil wells of Qayarrah sub-district hold 800 million barrels of estimated oil reserves. The field was explored by British Oil Development Company in 1927 , and production commenced during 1930., therefore the duration of the oil well fires was determined by the United Nations Institute for Training and Research Operational Satellite Applications Programme (UNITARUNOSAT) using fire detection data made it available by the NASA Fire Information for Resource Management System [5]. The monitoring showed that an initial fire occurred on 8 May 2016, then the fire is continued in 19 oil wells where this study is displaying their disadvantages. The international space agencies (NASA, NOAA) have detected the fires lasted to about the 12th. of July. Satellite monitoring showed that the area around the Qayyarah oil fields has been exposed to oil smoke plumes for about 90 days. Images by the NASA Earth Observatory showed the smoke plume spreading across northern Iraq, Syria, and Turkey, and acidic rain was reported which fall during the 28-29th. of October according to meteorological forecasts carried out by the State Meteorological Agency of Turkey[6]. That the smoke influenced peoples health in the short term where hundreds of people got medicinal treatments for the exposure to chemicals, and millions are exposed to soot and gases from the burning of oil wells, the land was degraded caused by unsustainable agricultural practices which causes desertification in the future. Also, the events caused environmental damage [7]. Acidic gases which were converted to acidic rain may damage the vegetation and increase the acidity of water resources. Agriculture may be temporarily affected, where the impacts will depend on the soil buffering capacity to pollutants [8,9]. Spread 


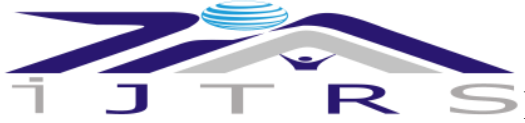

International Journal of Technical Research \& Science

of the smoke and the contaminating pollutants, the soot which covered the land, in particular by the wind and rainwater $[10,11,12]$. Which requires documented health registry of the exposed population to monitor and identify the long-term effects on health due to air pollution, by the Iraqi Ministry of Health and Environment foundations. Neighboring countries should also carry out similar monitoring activities[13,14]. Environmental conditions also need to be thoroughly assessed as soon as the situation allows. This can be carried out as part of a multi-lateral Post-Conflict Needs Assessment (PCNAs) undertaken by the UN Development Group. The European Commission in collaboration with the Government of Iraq. Alternatively, Environmental Assessment (PCEA) may be carried out by the Iraqi Government in collaboration with relevant international partners. Also, the fires of Qayarrah oil wells and smoke plumes were detected by satellites illustrations in the south of Mosul by (UN Operational Satellite Applications Programmer (UNOSAT) [15.16].

\section{RESEARCH IMPORTANCE}

The first objective of this study is to assess the adverse impact of oil wells combustion on sustainable development and on the other productivity sectors and how to get rid of their harmful effects and how to rehabilitate the infrastructure of these oil fields and to revivify the productive sites and how to protect the neighborhoods from their effects. The second objective is to identify the secondary serious dangers of the oil wells combustion on Qayarrah region with all kinds of pollution on the biosphere like the emission of gases and the accumulation of wastes, acid rains, heavy soil sediments and their impact on sustainable development due to wars and terrorist operations and rehabilitating the damaged biosphere.

\section{MATERIALS AND METHODS}

This research was conducted by using spatial analysis for the site of oil wells number (90). Especially in environmental challenges such as pollution. We must resort to scientific methods to determine the size of the problem and application of scientific research and technical advanced means, which is characterized by accuracy and speed. Analysis of oil wells combustion in the Qayyarah region in Nineveh province depend on aerial maps data, information of remote sensing and geo-ecological survey using Space Information Systems by the two agencies (NASA) and (NOAA) for environmental monitoring data, general authority of meteorological and also seismic monitoring systems and field survey systems. Among the factors which were used to assess the damages in this study The spatial analysis considers the better method to obtain data to measure the spatial harmful so as to ensure the scientific explanation of the relationship between spatial and changing factors in favor of the analysis and evaluation through understanding the causes of the present biosphere and its natural balance, distribution of geo-ecology of natural factors on the earth surface in order to ensure sustainable life development for all living organisms interacting with each other in the ecosystem, to predict the behavior of natural phenomenon such as pollution and the use of spectroscopy detection technique based on the process (Pixel) wise and their dimensions on the level of environmental, social, economic and spatial analysis. This problem gives a clear picture to pollution by oil combustion, which affects the land and associated factors including the stability of various human activities. Among the most important adopted indicators in variable ecosystems, degradation of vegetative cover, climate, weather topography, water resources, valleys, artificial pastures, nature pastures, geomorphological, geological features, natural resources (air, water and soil) characteristics.

\section{RESULTS AND DISCUSSION}

Nineveh province is located in the north western part of Iraq between longitudes $\left(41^{\circ}-25\right)\left(44^{\circ}-25\right)$ and latitudes $\left(34^{\circ}-55\right)\left(37^{\circ}-03\right)$ in the semi-arid region according to the global environmental classification, Its area is $7323 \mathrm{~km} 2$ it is also affected by the climate of the Mediterranean Sea [03,17], The troubled region is Qayyarah, Which is located $60 \mathrm{~km}$. in the south of Nineveh Governorate on the west bank of the Tigris river. The population is about 15,000. The Qayyarah town is located near the oil fields and has an oil refinery on its south-western outskirts [18,19]. The town of Qayyarah contains 63 oil wells, 19 wells were burned in May 2016 by terrorists, and that caused a casting of black cloud over the city for 3 months. That the released gases and other materials influenced the environment around the Qayyarah city which affect all the nearby natural resources such as; water, vegetative cover, and agrarian crops by acid rain [20]. The effects reached even the groundwater which become polluted and unusable due to high sulfate and mineral contents. The burning of oil wells has a long-lasting effect on the environment which depend on the amount of oil spilled and forming lakes or ponds of oil on the soil surface. [21] This disaster requires continuous efforts to assess health and ecological effects, as well as the polluted areas by wind to identify the long-term effects on health. The Iraqi health authorities should carry on a study on this disaster and even the neighbouring countries to evaluate the size of damage and presenting suggestions to overcome the side effects and risks of this trouble. Feedback and verification of field partners can be helpful to assess the effects on health and environment, and the effects on agricultural production and other economic activities which depend on the soil and water resources [24]. Also, rainfalls and associated flooding are causing additional concern as pollutants are being washed out from polluted sites by run-off as well as the deposited pollutants through the rain on agricultural fields and movement into the Tigris river [25,26]. Necessary precautions should be taken to minimize the negative effects of polluted rain and associated flooding to reduce the effects of toxic pollutants on the biosphere. Oil is a heavy viscous black 


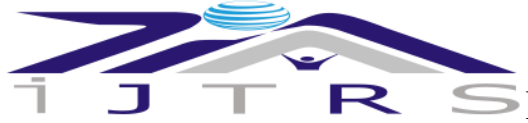

\section{International Journal of Technical Research \& Science}

material consists of many aromatic and aliphatic hydrocarbons in addition to many metallic elements such as sulfur and iron [27,28]. Ecologically, Oil burning causes the emission of natural gases including; methane, ethane, propane, and butane in addition to ethylene, which is the starting point of most important hydrocarbons polluting the air [29,30]. Oil burning causes an overshadow of sunlight and reduces airflow which affects the microbial activity contributing in the decomposition of organic wastes and vegetation residues. Burning the oil wells also lead to the escalation of vapors of certain acids such as; phosphoric acid, nitric acid which lead to the emergence of acid rain and finally these gases lead to increase the global warming and this increase is mainly attributed to an increase in carbon dioxide emission in the atmosphere [31,32]. Smoke plume carried with the winds covered the northern region of Iraq. In recent years the periodic oil fires have cast a dark pall over this arid land. They are of the one consequences of the ongoing war in the region. At August 17th. 2016 that the Operational Land Imager (OLI) on Landsat 8 acquired an image of dense smoke plumes roughly 50 kilometers south of Mosul. Which showed multiple sources of burnings in the Qayyarah oil fields. The images in the grid showed the plumes changing direction and thickness since they were first spotted by Landsat 8 on the 14th. Of June [33]. Oil wells which were burned in northern Iraq for several months and identified by NASA satellites. first detected fires at one or two wells near the towns of Qayyarah and Shargat regions in May, then it continued and in 19 oil wells and were monitored by NASA and NOAA agencies. [34]. Small fires were continued to spring up intermittently throughout June. Where the number and volume of fires increased dramatically from July 2016 onward then satellites returned to daily imaging showed clouds of thick black smoke streaming from the Qayyarah oil field. NASA satellites last detected a smoke from the oil field on March 27, 2017 [35]. Iraqi oil ministry made a formal announcement about the end of the fires on April 4, 2017. Of the 63 oil wells in the area burned 19 of them on fire by terrorists. The Operational Land Imager (OLI) on Landsat 8 captured these falsecolor images on January 24, 2017, and March 29, 2017. The images combine shortwave-infrared, and green light (OLI bands 6-5-3) to show active fires (bright red) and black smoke. NASA Earth Observatory images by Joshua Stevens, using Landsat data from the U.S. Geological Survey [36,37]. Economically the burning of oil wells has a negative impact on the economic development due to the absence of oil investment, the costs of rehabilitation of oil fields Is very high. Decrease were caused in agricultural production in both crop and animal activities, reduction of the fertility of soil due to acid rain, leaving the land without exploitation and degradation of biodiversity. Socially; people migration to a safe haven, loss of interaction between the community and its environment due to the loss of security \& pollution, deterioration of health for people living in the area of Qayyarah region \& its suburbs and the emergence of deaths \& diseases due to the poisoning by the hydrocarbon gases where detected. the pollutants were transported with number of factors such as spreading, natural dispersion, dissolution, emulsification, drifting, evaporation, sedimentation, oxidation and biodegradation, fig. 4.1.

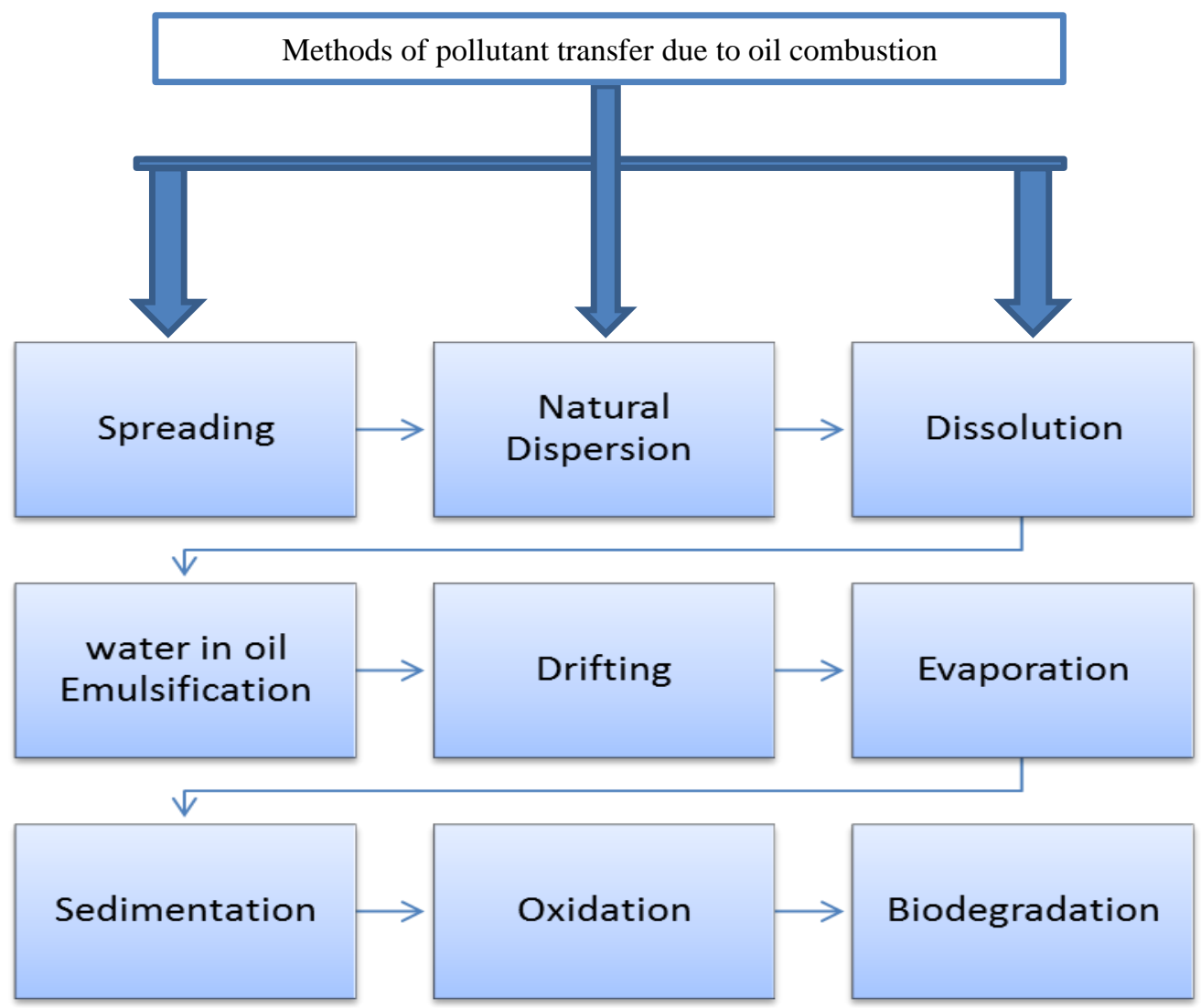

Fig. 4.1 Reveals the Methods of Pollutant Transfer due to Oil Combustion DOI Number: https://doi.org/10.30780/IJTRS.V06.I03.001 


\section{CONCLUSION}

It is clear from this research that the military operations and the accompanying terrorists operations shared in the burning of 19 oil wells out of 63 wells in the vicinity of Nineveh province had a significant effect on the destruction of the entire system of life and their reflections on sustainable development; Environmentally, economically and socially.

\section{RECOMMENDATION}

we recommend to conduct more studies to find suitable solutions in parallel to the destruction of the regions, and Rehabilitation of natural resources such as agricultural lands by planting fast-growing crops as clover, alfalfa and buckwheat and mixing with the soil and plowing processes to allow the these plants to convert contaminating substances into organic compounds by photosynthesis.

\section{REFERENCES}

[1] Abbas, N., Wasimi, S., Al-Ansari, N., \& Sultana, N. ,2018, Water resources problems of Iraq: Climate change adaptation and mitigation. Journal of Environmental Hydrology, 26. http://www.divaportal.org/smash/record.jsf?pid=diva2\%3A1206419\&dswid=35 70 .

[2] Abdulrahman, S.A., 2018. The drying up of the Lower Zab River and future water disputes between Iran, Kurdistan Region and Iraq, International Journal of Environmental Studies, 75:1, 29-44.

[3] Aliyas. I, 2016. Impact of Military Actions on Sustainable Development in Iraq. IRA-International Journal of Applied Sciences (ISSN2455-4499), 4(2), 351-357.

[4] Ibrahim M. Aliya,2016, Dimensions of Desertification on Sustainable Development in Iraq, Int. J. Adv. Res. 4(9), 1553-1556.

[5] Qayyarah oil field" ,2016, Open Oil Wiki.Retrieved 2015-06-15.

https://www.humanitarianresponse.info/en/operations/iraq/document/iraq-mosul-humanitarian-responsesituation-report-no-2-20-22-october-2016.

[6] Internal draft, WHO Geneva, Oil-well fires, Health hazards, Joanna Tempowski, October 21, 2016. WHO Press release, 24 October, http://www.emro.who.int/irq/iraq-news/who-and-ministry-of-healthmanage-over-1000-cases-of-suffocation.html.

[7] WHO internal draft - Possible short-term and long-term health effects of persistent fumes from al-Mishraq Sulfur factory, October 24th, 2016.

[8] Ibrahim, Jathwa A.,2011, "Pollution of mining industry sulphur purification plant at Al Mishraq, Journal of Engineering, Report Number 5, Volume 17 October 2011 http://www.iasj.net/iasj?func=fulltext\&aId=2790. 11- NASA Earth Observatory images by Joshua Stevens, using data provided courtesy of the Aura OMI science team and MODIS data from LANCE/EOSDIS Rapid Response. Caption by Adam Voiland. http://earthobservatory.nasa.gov/NaturalHazards/view.php?id=88994.

[9] Mosher, Dave, "ISIS militants have spread a toxic, corrosive cloud over parts of Syria, Iraq, and Turkey", Business Insider, UK, October 25th, 2016 http://uk.businessinsider.com/mosul-sulfur-fire-smoke-spacenasa-2016-10? $r=U S \& I R=T$.

[10] WHO report - WHO supports Iraqi capacity-building on mass casualty management of chemical agents usage, October 24th, 2016 http://www.emro.who.int/irq/iraq-news/who-supports-iraqi-capacity-buildingon-mass-casualty-

[11] Management-of-chemical-agents-usage.html Environmental Damage as a Weapon of War? Open Source Industrial Risk Analysis of the Mosul Battle", Wim Zwijnenburg, October 25th, 2016.

[12] https://www.bellingcat.com/news/mena/2016/10/25/environmental-damage-weapon-war-open-sourceindustrial-risk-analysis-mosul-battle.

[13] NASA Report - Kuwait oil fires http://visibleearth.nasa.gov/view.php?id=78594.

[14] NASA Modis Report - Oil fires in Iraq, August 10, 2016 https://modis.gsfc.nasa.gov/gallery/individual.php?db_date=2016-08-20.

[15] UNEP, Assessment of Environmental "Hot Spots" in Iraq, October 2005.

[16] UNEA Resolution 2/15 - Protection of the environment in the areas affected by armed conflict. http://www.unep.org/about/sgb/cpr_portal/Portals/50152/2-15/K1607252_UNEPEA2_RES15E.pdf

[17] UN HRC (A/HRC/33/41 Report of the Special Rapporteur on the implications for human rights of the environmentally sound management and disposal of hazardous substances and wastes https://www.crin.org/sites/default/files/childrensrightstoxics.pdf

[18] Iraq: Mosul Humanitarian Response Situation Report No. 2 (20-22 October) 2016. https://www.humanitarianresponse.info/en/operations/iraq/document/iraq-mosul-humanitarian-responsesituation-report-no-2-20-22-october-2016

[19] Internal draft - WHO Geneva - Oil-well fires - Health hazards, Joanna Tempowski, October 21, 2016 


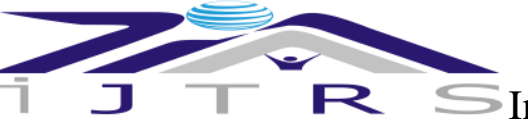

[20] WHO Press release, 24 October, http://www.emro.who.int/irq/iraq-news/who-and-ministry-of-healthmanage-over-1000-cases-of- suffocation.html.

[21] WHO ,2016, internal draft - Possible short-term and long-term health effects of persistent fumes from alMishraq Sulfur factory, October 24th, 2016.

[22] -2224- Ibrahim, Jathwa A., "Pollution of mining industry sulphur purification plant at Al Mishraq, Journal of Engineering, Report Number 5, Volume $17 \quad$ October 2011. http://www.iasj.net/iasj?func=fulltext\&aId=2790.

[23] NASA Earth Observatory images by Joshua Stevens, using data provided courtesy of the Aura OMI science team and MODIS data from LANCE/EOSDIS Rapid Response. Caption by Adam Voiland. http://earthobservatory.nasa.gov/NaturalHazards/view.php?id.

[24] Mosher, Dave, "ISIS militants have spread a toxic, corrosive cloud over parts of Syria, Iraq, and Turkey", Business Insider, UK, October 25th, 2016. http://uk.businessinsider.com/mosul-sulfur-fire-smoke-spacenasa-2016-10? $\mathrm{r}=\mathrm{US} \& \mathrm{IR}=\mathrm{T}$.

[25] WHO report - WHO supports Iraqi capacity-building on mass casualty management of chemical agents usage, October 24th, 2016. http://www.emro.who.int/irq/iraq-news/who-supports-iraqi-capacity-buildingon-mass-casualty. management-of-chemical-agents-usage.html

[26] Environmental Damage as a Weapon of War2016,Open Source Industrial Risk Analysis of the Mosul Battle", Wim Zwijnenburg, October 25th.

[27] NASA Modis Report - Oil fires in Iraq, August 10, 2016 https://modis.gsfc.nasa.gov/gallery/individual.php?db_date=2016-08-20.

[28] UNEP, Assessment of Environmental "Hot Spots" in Iraq, October 200.5 http://postconflict.unep.ch/publications/Iraq_ESA.pdf.

[29] UNEA Resolution $2 / 15$ - Protection of the environment in the areas affected by armed conflict http://www.unep.org/about/sgb/cpr_portal/Portals/50152/2- 15/K1607252_UNEPEA2_RES15E.pdf.

[30] UN HRC (A/HRC/33/41 Report of the Special Rapporteur on the implications for human rights of the environmentally sound management and disposal of hazardous substances and wastes.

[31] https://www.crin.org/sites/default/files/childrensrightstoxics.pdf.

[32] Albawaba , 2016, Oil Fires Burn Across Qayyarah After Iraqi Army Retakes City from Daesh. Accessed August 31, 2016.

[33] NASA Earth Observatory (2016, September 2) Oil Fires in Iraq.

35- Relief web , 2017, Iraq: Fires at the Al Qayyarah Oil Field, Nineveh Governorate, between 18 July 2016 and 7 January 2017. Accessed April 4, 2017.

[34] Rudaw ,2017, burning Qayyarah oil wells brought under control. Accessed April 4, 2017.

[35] Time ,2017, Meet the Iraqi Firefighters Battling ISIS' Oil Fires. Accessed April 4, 2017. 